\title{
The genotypic relationship of Candida albicans strains isolated from the oral cavity of patients with denture stomatitis
}

\author{
L. T. MATHABA, G. DAVIES and J. R. WARMINGTON*
}

School of Biomedical Sciences, Curtin University of Technology, GPO Box U1987, Perth 6001, Western Australia, Australia

\begin{abstract}
Summary. Fifty-seven isolates of Candida albicans were obtained from different sites within the oral cavities of 18 dental patients without AIDS or any malignancies. Eleven of the patients had oral candidosis associated with the wearing of dentures. The genotypic relationships of the individual isolates were determined by hybridisation of a C. albicansspecific moderately repetitive sequence, 27A, to EcoRI-digested $C$. albicans chromosomal DNA. From the DNA profiles, the isolates could be divided into 22 distinct genetic groups. In the majority of patients, a single unique strain of $C$. albicans appeared to dominate in the oral cavity. Re-infection following antifungal therapy was generally due to the re-emergence of the original infecting strain. The $C$. albicans strains isolated from dental plates did not form a distinct genetic group. These results suggest that denture stomatitis is due to the outgrowth of commensal strains of $C$. albicans.
\end{abstract}

\section{Introduction}

Candida albicans is a normal commensal of the oral cavities of healthy individuals. The frequency of candida carriage in normal individuals varies from $10 \%$ to $50 \%$ depending upon the method of sampling. ${ }^{1}$ In recent times there has been much interest in oral candidosis, as it is the most frequent opportunist infection in patients with AIDS. ${ }^{2}$ However, oral candidosis is a significant cause of morbidity in denture wearers, the majority of whom do not have AIDS. ${ }^{3}$ Denture stomatitis is regarded as numerically the most common form of candida-associated disease. It is an especially severe form of chronic oral candidosis on the mucous surfaces that are covered by dental plates. ${ }^{4}$ The ability of $C$. albicans to adhere to oral epithelia and plastic surfaces, including dentures, is probably a major factor in establishing colonisation and pathology. ${ }^{3}$ Despite the severity and frequency of denture stomatitis, little is known about the epidemiology of the infection. Further studies are necessary to determine the origin and clonal nature of $C$. albicans strains associated with denture stomatitis. The relationship of these strains, and re-infecting strains, to the commensal $C$. albicans isolates should also be determined. DNA-based typing assays provide a useful tool to determine the genotypic relationship of clinical C. albicans isolates. Molecular techniques have been used to type $C$. albicans isolates from various body sites of patients with different forms of candidosis. $^{5-9}$

In the present study, isolates of $C$. albicans were obtained from 18 patients with oral thrush. Eleven of the patients had denture-induced stomatitis; the remaining seven patients were edentulous. Chromosomal DNA was extracted from each of the isolates and analysed by restriction endonuclease analysis (REA) and hybridisation with a $C$. albicans-specific intermediate repetitive DNA probe, $27 \mathrm{~A} .{ }^{10}$ The genetic relationship of the isolates was determined from the resulting DNA profiles by the use of computer constructed dendrograms. The ability of these isolates to produce germ tubes was also compared and correlations with site of isolation were determined.

\section{Materials and methods}

Organisms and growth conditions

Fifty-seven $C$. albicans isolates, from oral swabs of 18 dental patients without any malignancies or AIDS, 
Table I. Sites of isolation of C. albicans from individual patients

\begin{tabular}{|c|c|c|c|c|}
\hline Patient & Sites sampled & $\begin{array}{c}\text { Number of times } \\
\text { sampled }\end{array}$ & $\begin{array}{l}\text { Number of } \\
\text { isolates }\end{array}$ & $\begin{array}{c}\text { Isolate } \\
\text { designation }\end{array}$ \\
\hline A & Tongue & 1 & 1 & $\mathrm{Aa}$ \\
\hline \multirow[t]{2}{*}{ B } & Tongue & 1 & 1 & $\mathrm{Ba}$ \\
\hline & Denture & 1 & 1 & $\mathrm{Bb} \ddagger$ \\
\hline \multirow[t]{2}{*}{$\mathrm{C}$} & Tongue & 1 & 1 & $\mathrm{Ca}$ \\
\hline & Palate & 1 & 1 & $\mathrm{Cb}$ \\
\hline \multirow[t]{3}{*}{ D } & Tongue & 2 & 3 & $\mathrm{Da}^{*}, \mathrm{Dd} \dagger, \mathrm{De} \dagger$ \\
\hline & Commissure & 2 & 3 & $\mathrm{Db}^{*}, \mathrm{Df} \dagger, \mathrm{Dg} \dagger$ \\
\hline & Left tonsil & 2 & 3 & $\mathrm{Dc}^{*}, \mathrm{Dh} \uparrow, \mathrm{Di} \dagger$ \\
\hline $\mathbf{E}$ & Palate & 1 & 1 & $\mathrm{Ea}$ \\
\hline \multirow[t]{3}{*}{$\mathbf{F}$} & Palate & 2 & 2 & $\mathrm{Fa}^{*}, \mathrm{Fc} \dagger$ \\
\hline & Tongue & 1 & 1 & $\mathrm{Fb}$ \\
\hline & Palate lesion & 1 & 1 & $\mathrm{Fd}$ \\
\hline \multirow[t]{3}{*}{$\mathbf{G}$} & Palate & 1 & 1 & $\mathrm{Ga}$ \\
\hline & Tongue & 1 & 1 & $\mathrm{~Gb}$ \\
\hline & Denture & 1 & 1 & Gct \\
\hline \multirow[t]{3}{*}{$\mathbf{H}$} & Palate & 1 & 1 & $\mathrm{Ha}$ \\
\hline & Denture & 1 & 1 & $\mathrm{Hb} \ddagger$ \\
\hline & Tongue & 1 & 1 & $\mathrm{Hc}$ \\
\hline \multirow[t]{2}{*}{ I } & Palate & 1 & 1 & Ia \\
\hline & Tongue & 1 & 1 & Ib \\
\hline \multirow[t]{3}{*}{$\mathbf{J}$} & Palate & 1 & 1 & $\mathrm{Ja}$ \\
\hline & Tongue & 1 & 1 & $\mathrm{Jb}$ \\
\hline & Denture & 1 & 1 & Jct \\
\hline \multirow[t]{3}{*}{$\mathbf{K}$} & Tongue & 2 & 2 & $\mathrm{Ka}^{*}, \mathrm{Kd} \dagger$ \\
\hline & Denture & 2 & 2 & $\mathrm{~Kb}^{*}, \mathrm{Ke}+\ddagger$ \\
\hline & Palate & 1 & 1 & $\mathrm{Kc}$ \\
\hline \multirow[t]{2}{*}{$\mathbf{L}$} & Denture & 1 & 1 & La $\ddagger$ \\
\hline & Tongue & 1 & 1 & $\mathrm{Lb}$ \\
\hline \multirow[t]{3}{*}{ M } & Palate & 2 & 2 & $\mathrm{Ma}^{*}, \mathrm{Mf} \dagger$ \\
\hline & Denture & 2 & 3 & $\mathrm{Mb}^{*} \ddagger, \mathrm{Md} \ddagger \neq, \mathrm{Me} \ddagger$ \\
\hline & Tongue & 1 & 1 & Mc \\
\hline \multirow[t]{3}{*}{$\mathbf{N}$} & Palate & 2 & 2 & $\mathrm{Na}^{*}, \mathrm{Nd} \dagger$ \\
\hline & Denture & 2 & 2 & $\mathrm{Nb}^{*} \ddagger, \mathrm{Ne}+\ddagger$ \\
\hline & Tongue & 1 & 1 & $\mathrm{Nc}$ \\
\hline \multirow[t]{3}{*}{$\mathrm{O}$} & Left tonsil & 1 & 1 & $\mathrm{Oa}$ \\
\hline & Right tonsil & 1 & 1 & $\mathrm{Ob}$ \\
\hline & Tongue & 1 & 1 & $\mathrm{Oc}$ \\
\hline \multirow[t]{3}{*}{$\mathbf{P}$} & Denture & 1 & 1 & Pał \\
\hline & Palate & 1 & 1 & $\mathrm{~Pb}$ \\
\hline & Tongue & 1 & 1 & Pc \\
\hline \multirow[t]{3}{*}{ Q } & Denture & 1 & 1 & Qał \\
\hline & Tongue & 1 & 1 & $\mathrm{Qb}$ \\
\hline & Palate & 1 & 1 & $\mathrm{Qc}$ \\
\hline \multirow[t]{2}{*}{$\mathbf{R}$} & Ridge & 1 & 1 & $\mathbf{R a}$ \\
\hline & Denture & 1 & 1 & Rbt \\
\hline
\end{tabular}

\footnotetext{
* Isolate from the primary infection.

$\uparrow$ Isolate from a secondary infection.

$\ddagger$ Isolate associated with denture stomatitis.
}

were kindly provided by Dr G. Davies, University of Western Australia Dental School. Eleven of the patients (patients B, G, H, J, K, L, M, N, P, Q and R) had denture-induced stomatitis; the remaining seven patients (patients A, C, D, E, F, I and O) were edentulous (table I). In nine patients, isolates were obtained from three different sites in and around the oral cavity. In another two patients from whom three sites sampled, isolates were obtained from only two of the sites. In three patients, four sites were sampled but in two of them only three of the sites yielded isolates while in the third patient only two sites gave positive cultures. Two sites were sampled in four patients. Both sites gave positive cultures in two of the patients, but only one site each was positive in the other two patients. All of the patients were sampled 7 days after the initiation of antifungal treatment and 30 days thereafter. No isolates were obtained 7 days after antifungal treatment, but 30 days later, five of the 18 patients (patients D, F, K, M and N) had positive cultures. Primary culture plates of most of the samples obtained at the two different times yielded only one colony phenotype; four samples yielded two colonial phenotypes each, such as smooth and rough colonies. Each of these different colonial phenotypes was included for typing. The yeast isolates were stored at $-20^{\circ} \mathrm{C}$ in glycerol $15 \% \mathrm{v} / \mathrm{v}$ and propagated on Sabouraud agar (peptone $1 \% \mathrm{w} / \mathrm{v}$, dextrose $4 \% \mathrm{w} / \mathrm{v}$, agar $1.5 \% \mathrm{w} / \mathrm{v}$, chloramphenicol $50 \mathrm{mg} / \mathrm{L}$, pH 5.6). For analysis, the isolates were grown in YEPD broth (yeast extract $1 \% \mathrm{w} / \mathrm{v}$, peptone $2 \% \mathrm{w} / \mathrm{v}$, glucose $2 \% \mathrm{w} / \mathrm{v}$ ) overnight, with aeration, at $30^{\circ} \mathrm{C}$. 


\section{Induction of germ tubes}

Several colonies were picked from each Sabouraud agar plate and grown in YEPD broth, with aeration, at $30^{\circ} \mathrm{C}$ overnight. Cells from the overnight cultures were harvested by centrifuging a $1-\mathrm{ml}$ sample at $13000 \mathrm{~g}$ for $30 \mathrm{~s}$. The cell pellets were washed twice with $1 \mathrm{ml}$ of sterile saline $(\mathrm{NaCl} 0.9 \% \mathrm{w} / \mathrm{v})$ and resuspended in $1 \mathrm{ml}$ of fresh saline. The cell concentration was adjusted to $c .10^{6}$ blastospores $/ \mathrm{ml}^{3}{ }^{3}$ The diluted cells were inoculated into horse serum (Commonwealth Serum Laboratories, Australia) $10 \% \mathrm{v} / \mathrm{v}$, prewarmed to $37^{\circ} \mathrm{C}$, and incubated at $37^{\circ} \mathrm{C}$ for $1 \mathrm{~h}$. Germ tube formation was observed by phase contrast microscopy at $\times 400$ magnification and the numbers of cells with germ tubes/field were counted. Three separate experiments were set up and three different fields were examined in each experiment.

\section{Restriction endonuclease analysis (REA) of C albicans chromosomal DNA and Southern hybridisation}

Restriction endonuclease digestion of $C$. albicans chromosomal DNA was performed as outlined previously. ${ }^{11}$ Each of the agarose blocks containing $C$. albicans DNA was incubated at $37^{\circ} \mathrm{C}$ for $6 \mathrm{~h}$ with $100 \mu \mathrm{l}$ of $E c o$ RI buffer, containing EcoRI (Toyobo, Japan) 20-50 units, nuclease-free bovine serum albumin (BSA) (Boehringer Mannheim GmbH, Germany) $0.2 \mathrm{mg} / \mathrm{ml}$, and $2 \mathrm{~mm}$ spermidine. The blocks were then dialysed with excess TE $(10 \mathrm{mM}$ Tris, $1 \mathrm{~mm}$ EDTA, pH 8.0). Each agarose block was melted at $65^{\circ} \mathrm{C}$, loaded on to an agarose $1 \% \mathrm{w} / \mathrm{v}$ gel (BioRad, USA) in $1 \times$ TAE buffer $(50 \times$ TAE is $2 \mathrm{~m}$ Tris-base, $0.1 \mathrm{M}$ EDTA, glacial acetic acid $5.71 \% \mathrm{v} / \mathrm{v})$, and electrophoresed in $1 \times$ TAE buffer at $2 \mathrm{~V} / \mathrm{cm}$ for $18 \mathrm{~h}$. A 1-kb ladder (Bethesda Research Laboratories, USA) was used as a molecular size marker. The DNA was transferred to nylon membranes (Hybond- $\mathrm{N}+$; Amersham) by alkali transfer. ${ }^{12}$ Briefly, the gels were soaked once in $0.25 \mathrm{M} \mathrm{HCl}$ for $8 \mathrm{~min}$, rinsed in distilled water and the DNA was blotted on to nylon membranes in transfer buffer $(0.4 \mathrm{M} \mathrm{NaOH}, 0.6 \mathrm{M} \mathrm{NaCl})$ for $4 \mathrm{~h}$. After transfer, the membranes were washed once in $50 \mathrm{ml}$ of $1 \mathrm{M}$ Tris- $\mathrm{HCl}$ for $30 \mathrm{~min}$ followed by two 15 -min washes in $50 \mathrm{ml}$ of $2 \times \mathrm{SSC}(20 \times \mathrm{SSC}$ is $150 \mathrm{mM}$ $\mathrm{NaCl}, 15 \mathrm{~mm}$ sodium citrate) and oven dried at $65^{\circ} \mathrm{C}$ for $30 \mathrm{~min}$.

A C. albicans-specific repetitive DNA segment, $27 \mathrm{~A}^{10}$ was radiolabelled by the random primer technique $^{13}$ and hybridised with the nylon membranes for $17 \mathrm{~h}$ at $65^{\circ} \mathrm{C}$ in $30 \mathrm{ml}$ of hybridisation solution $(2 \times$ SSPE, SDS $1 \% \mathrm{w} / \mathrm{v}$, BSA $1 \% \mathrm{w} / \mathrm{v})$ containing $0.3 \mathrm{ml}$ of sonicated salmon sperm DNA $(10 \mathrm{mg} / \mathrm{ml})$. The membranes were rinsed in $50 \mathrm{ml}$ of $2 \times \mathrm{SSC}$ for $1 \mathrm{~min}$, washed in $50 \mathrm{ml}$ of $2 \times \mathrm{SSC}$, SDS $0.1 \% \mathrm{w} / \mathrm{v}$ at room temperature for $15 \mathrm{~min}$ followed by a 10-min wash in $50 \mathrm{ml}$ of $0.5 \times \mathrm{SSC}$, SDS $0.1 \% \mathrm{w} / \mathrm{v}$ at $65^{\circ} \mathrm{C}$ with vigorous shaking and, finally, a brief rinse in $50 \mathrm{ml}$ of $0.5 \times \mathrm{SSC}$, SDS $0.1 \% \mathrm{w} / \mathrm{v}$ at room tem- perature. The membrane-bound labelled probe was detected by autoradiography with Kodak X-OMAT AR-5 film and a DuPont Quanta III intensifying screen.

\section{Results}

\section{REA and Southern hybridisation}

Hybridisation of the $C$. albicans-specific DNA probe, 27A to Southern blots of EcoRI-digested DNA of individual isolates produced 5-15 bands, with both highly conserved and variant bands (fig. 1). Differences in the positions and intensity of the bands enabled the relationship of the different $C$. albicans isolates to be determined. To quantify differences between the individual banding patterns, the molecular size and intensity of each band was scored as described by Schmid et al..$^{5}$ The DOLLOP program ${ }^{14}$ was used to construct a dendrogram showing the relationships of the 28 clinical isolates, by comparing the score matrix of individual profiles with each other (fig. 2). On the basis of the DNA band patterns, the 57 isolates were distributed into 22 genetic groups (i-xxii) (table II). Four of the 22 groups (iv, viii, xii and xxii) contained $12 \%$ ( 7 of 57 ), $10.5 \%$ ( 6 of 57 ), $8.8 \%$ ( 5 of 57 ) and $14 \%$ ( 8 of 57 ) of the isolates, respectively. The remaining 18 groups contained three or less isolates.

The majority of the C. albicans isolates obtained from different sites within the oral cavity of an individual patient had a similar genotype (table II). Generally, each patient was colonised by a C. albicans strain that had a unique genotype not found in any other patient. In cases where the same patient was infected by strains belonging to more than one genetic group, as in patients $\mathrm{D}, \mathrm{F}, \mathrm{I}$ and $\mathrm{O}$, at least one of the groups was unique to that patient. Patient $\mathrm{M}$ had three different groups, all of them unique to that patient. Patient $\mathrm{N}$ had four different groups, three of which were unique to this patient. Patient $O$ was infected by two strains, one of which was unique to this patient. Patient $F$ also had two strains, one of which was not found in any other patient. Furthermore, in such instances where multiple genetic groups existed within a single patient, one of the genetic groups appeared to be predominant over the other group(s). For example, strains belonging to genetic group iv were obtained from three oral sites of patient $\mathrm{D}$ every time the sites were sampled, whereas two strains belonging to a different unrelated group (group v) were each isolated only once during the secondary infection. The same applied to patient $\mathrm{F}$, from whom group vii was represented three times at two sites, whereas group viii was represented only once. In patient $\mathrm{M}$, group xvi was represented three times whereas groups xiv and $x v$ were each represented only once; and in patent $\mathrm{N}$, group xviii was represented twice and groups xvii, xix and $\mathrm{xx}$ were each represented only once.

Strains of $C$. albicans belonging to three of the 22 genetic groups colonised more than one patient. For 


\section{$\frac{H}{123} \frac{\mathrm{I}}{45} \frac{\mathrm{J}}{678} \frac{\mathrm{K}}{910111213141516}$}

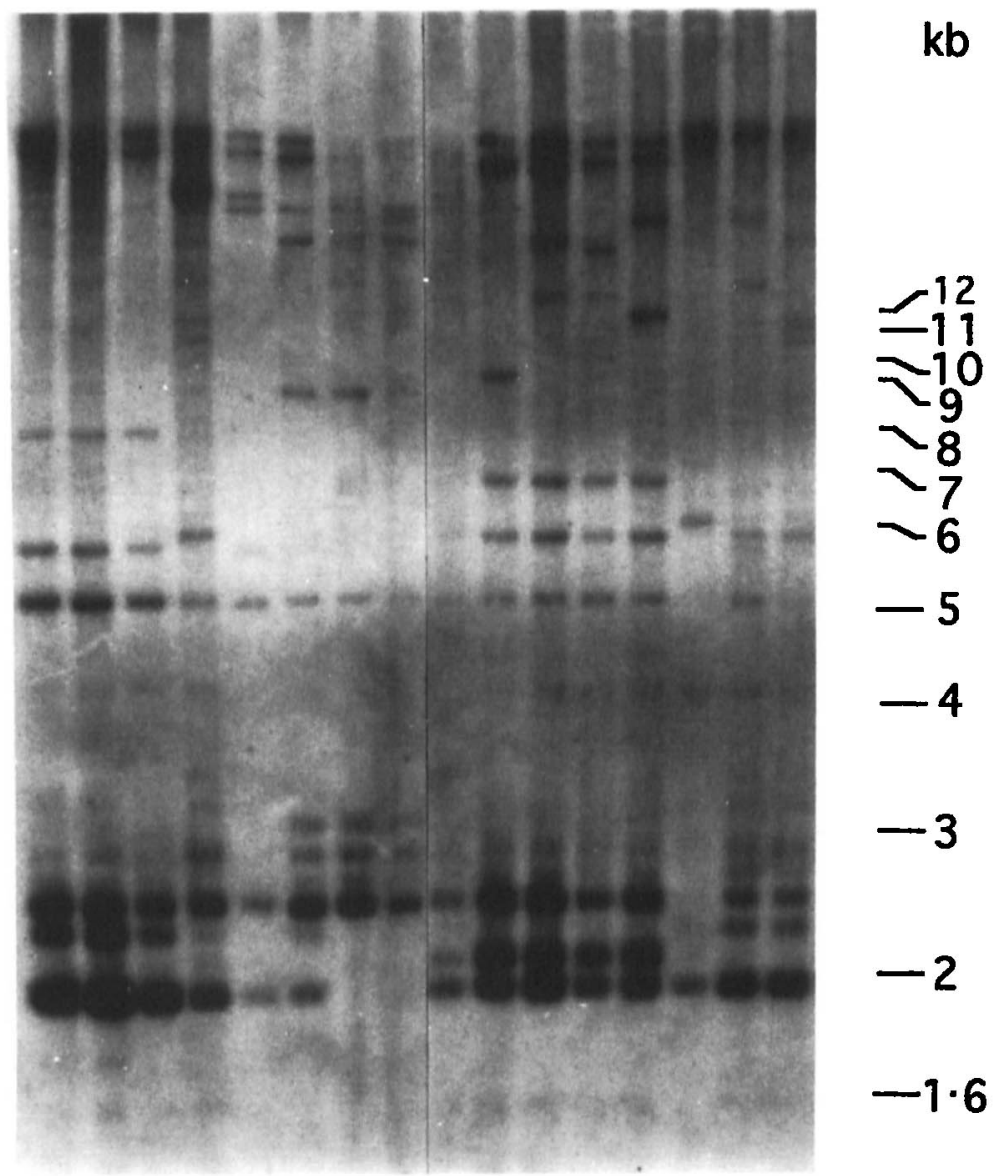

Fig. 1. An autoradiogram showing the DNA fingerprint patterns of 16 of the 57 C. albicans isolates after hybridisation analysis of EcoRIdigested total cellular DNA with the ${ }^{32} \mathrm{P}$-labelled mid-repeat sequence $C$. albicans-specific DNA probe, 27A. At the top of the figure are the patient numbers: lanes 1-3, isolates from patient $\mathrm{H} ; 4$ and 5 , isolates from patient $\mathrm{I} ; \mathbf{6 - 8}$, isolates from patient $\mathrm{J} ; \mathbf{9 - 1 3}$, isolates from patient $\mathrm{K}$; 14-16, isolates from patient $\mathrm{Q}$. Molecular sizes of the fragments are given on the right of the figure.

example, three patients ( $\mathrm{F}, \mathrm{G}$ and $\mathrm{H})$ were infected by strains belonging to genetic group viii. All the strains from patients $P, Q$ and $R$ belonged to the same genetic group, xxii. Two patients ( $\mathrm{N}$ and $\mathrm{O}$ ) were infected by strains from group $\mathrm{xx}$; six of these eight patients sharing the same genetic groups were denture wearers.

In five of the 18 patients, C. albicans isolates were obtained from a secondary infection which occurred after antifungal therapy. The strains of $C$. albicans involved in secondary infections are identified with a $\dagger$ in table II. In patients $\mathrm{F}$ and $\mathrm{K}$, the secondary infection was due to the same strain that caused the primary infection. In contrast, in patients $\mathrm{M}$ and $\mathrm{N}$, the secondary infection was due to a different, unrelated strain. In patient $\mathrm{D}$, two isolates each were obtained from the tongue, commissure and left tonsil, and in each case the two isolates had different colony morphologies. The pair from the tongue belonged to the same genetic group (iv) as the strain which had caused the primary infection. For both the commissure and left tonsil, one of the re-infecting strains was the same as the original strain and the re-infecting strains on the tongue, whereas the second strain belonged to a new genetic group. Two isolates were obtained from the dentures of patient $\mathbf{M}$ during the secondary infection and these isolates had different colony morphologies. However, these two isolates belonged to the same genetic group (xvi). Those strains involved in reinfection also did not fall into a single genetic group, but were divided among seven of the 22 genetic groups, as shown in table II.

\section{Colony phenotypes of the clinical isolates of $C$. albicans}

Colony phenotypes of the isolates were determined from the primary culture plates. The predominant colony phenotype in all 57 isolates was a smooth, white $(\mathrm{Sw})$ phenotype, irrespective of the site of isolation (table II). Only five samples contained strains that exhibited minor variant colony phenotypes and these variant colony phenotypes were observed mainly in secondary infections. Three of these variant colony phenotypes had a white colony with a rough surface and a regular edge, one had petite smooth white colonies, while the fifth had colonies that were smooth 


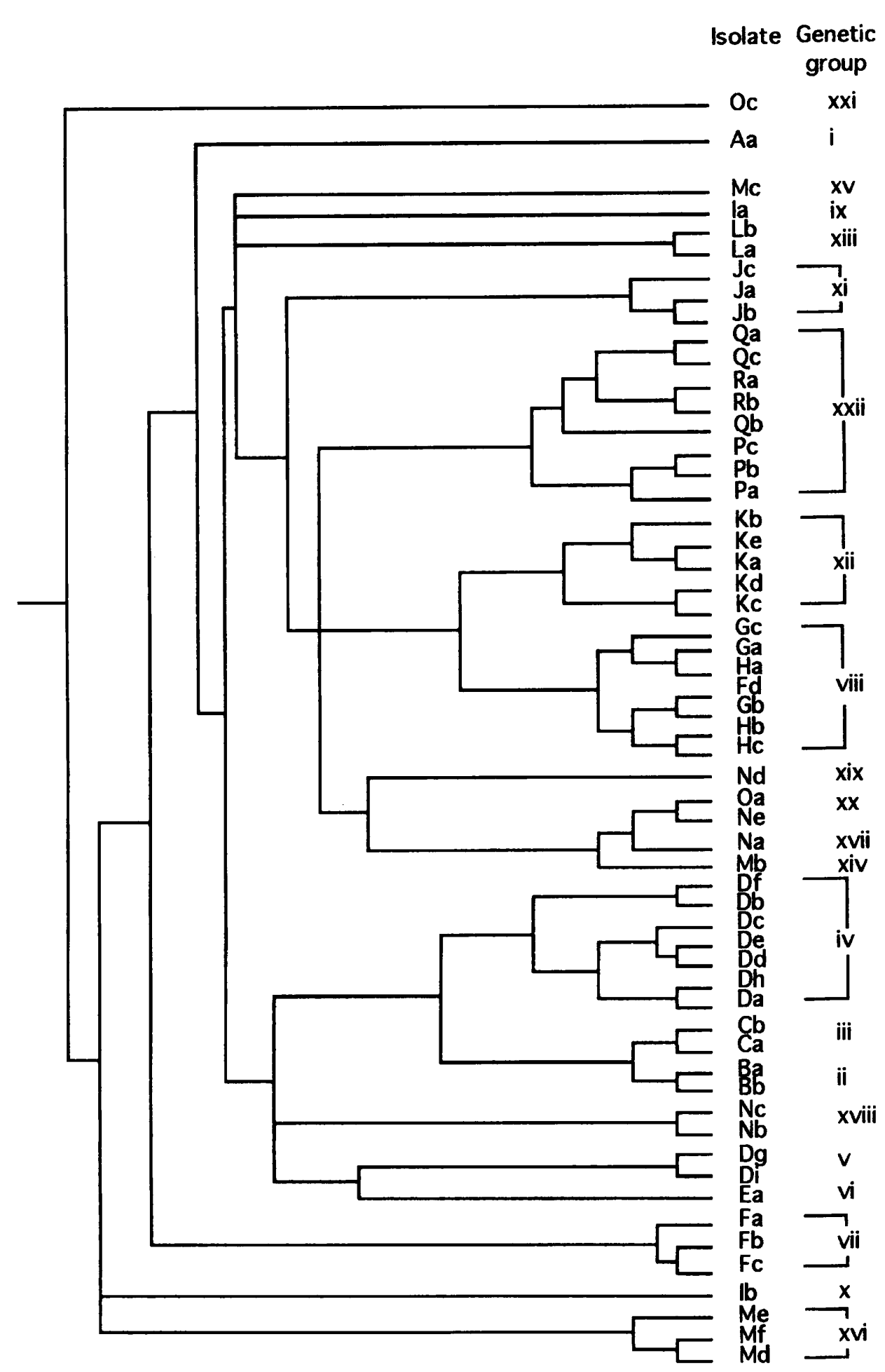

Fig. 2. Dendrogram showing the relationships of the 57 clinical isolates of $C$. albicans. The isolates were distributed into 22 genetic groups (i-xxii) shown to the right of the dendrogram.

and white but much larger than characteristic $C$. albicans colonies. Two of the rough, regular edge colony phenotypes were from a single patient (patient D), one from the commissure and another from the left tonsil. Both of these isolates were placed in the same genetic group by DNA fingerprinting with probe $27 \mathrm{~A}$. These two isolates were different from the rest of the isolates from patient $D$. No new colony phenotypes were observed on subculture.
Germ tube formation by clinical isolates of C. albicans

The ability of the isolates to form germ tubes was investigated in horse serum in triplicate. Germ tube formation by each isolate was reproducible and ranged from $5 \%$ to $95 \%$ (table III); in $22 \%$ of the isolates, $>95 \%$ of the cells formed germ tubes, while in $32 \%$ of isolates $50-90 \%$ of the cells formed germ tubes, and in $46 \%$ of isolates $<50 \%$ of cells formed germ tubes. 
Table II. Colony morphologies of the $C$. albicans isolates and genetic groups as determined from the dendrogram

\begin{tabular}{|c|c|c|c|c|}
\hline Patient & Sites sampled & Isolate designation & Colony morphology & Genetic group \\
\hline A & Tongue & $\mathrm{Aa}$ & Sw & $\mathrm{i}$ \\
\hline \multirow[t]{2}{*}{ B } & Tongue & $\mathrm{Ba}$ & Sw & ii \\
\hline & Denture & $\mathrm{Bb} \ddagger$ & Sw & ii \\
\hline \multirow[t]{2}{*}{$\mathrm{C}$} & Tongue & $\mathrm{Ca}$ & Sw & iii \\
\hline & Palate & $\mathrm{Cb}$ & Sw & iii \\
\hline \multirow[t]{7}{*}{ D } & Tongue & $\mathrm{Da}^{*}$ & Sw & iv \\
\hline & & Dd $\dagger$ & Petite sw & iv \\
\hline & & $\operatorname{De} \dagger$ & Large sw & iv \\
\hline & Commissure & $\mathrm{Db}^{*}, \mathrm{Df} \dagger$ & Sw & iv \\
\hline & & $\mathrm{Dg} \dagger$ & Rough, R/Edge & $\mathrm{v}$ \\
\hline & Left tonsil & $\mathrm{Dc}^{*}, \mathrm{Dh} \dagger$ & Sw & iv \\
\hline & & $\mathrm{Di} \dagger$ & Rough, R/Edge & $\mathrm{v}$ \\
\hline E & Palate & $\mathrm{Ea}$ & Sw & vi \\
\hline \multirow[t]{3}{*}{$\mathrm{F}$} & Palate & $\mathrm{Fa}^{*}, \mathrm{Fc} \dagger$ & Sw & vii \\
\hline & Tongue & $\mathrm{Fb}$ & Sw & vii \\
\hline & Palate lesion & Fd & Sw & viii \\
\hline \multirow[t]{3}{*}{ G } & Palate & $\mathrm{Ga}$ & Sw & viii \\
\hline & Tongue & $\mathrm{Gb}$ & Sw & viii \\
\hline & Denture & Gc & Sw & viii \\
\hline \multirow[t]{3}{*}{$\mathrm{H}$} & Palate & $\mathrm{Ha}$ & Sw & viii \\
\hline & Denture & $\mathrm{Hb} \ddagger$ & Sw & viii \\
\hline & Tongue & $\mathrm{Hc}$ & Sw & viii \\
\hline \multirow[t]{2}{*}{ I } & Palate & Ia & Sw & ix \\
\hline & Tongue & $\mathrm{Ib}$ & Sw & $\mathrm{x}$ \\
\hline \multirow[t]{3}{*}{$\mathbf{J}$} & Palate & $\mathrm{Ja}$ & Sw & $\mathrm{xi}$ \\
\hline & Tongue & $\mathrm{Jb}$ & $\mathrm{Sw}$ & $\mathrm{xi}$ \\
\hline & Denture & Jc $\ddagger$ & Sw & $\mathrm{xi}$ \\
\hline \multirow[t]{3}{*}{ K } & Tongue & $\mathrm{Ka}^{*}, \mathrm{Kd} \dagger$ & Sw & xii \\
\hline & Denture & $\mathrm{Kb}^{*}$, Ke $† \ddagger$ & Sw & xii \\
\hline & Palate & $\mathrm{Kc}$ & Sw & xii \\
\hline \multirow[t]{2}{*}{ L } & Denture & Lał & Sw & xiii \\
\hline & Tongue & $\mathrm{Lb}$ & Sw & xiii \\
\hline \multirow[t]{6}{*}{$\mathbf{M}$} & Palate & $\mathrm{Ma}^{*}$ & Sw & ND \\
\hline & & Mf $\dagger$ & Sw & xvi \\
\hline & Denture & $\mathrm{Mb}^{*} \ddagger$ & Sw & xiv \\
\hline & & $\mathrm{Md}+f$ & Sw & xvi \\
\hline & & $\operatorname{Met} \ddagger$ & Rough, R/Edge & $x v i$ \\
\hline & Tongue & Mc & Sw & $\mathrm{xv}$ \\
\hline \multirow[t]{5}{*}{$\mathrm{N}$} & Palate & $\mathrm{Na}^{*}$ & $\mathrm{Sw}$ & $\mathrm{xvii}$ \\
\hline & & $\mathrm{Nd}+$ & Sw & xix \\
\hline & Denture & $\mathrm{Nb}^{*} \ddagger$ & Sw & xviii \\
\hline & & $\mathrm{Ne} \uparrow$ & $\mathrm{Sw}$ & $\mathrm{xx}$ \\
\hline & Tongue & $\mathrm{Nc}$ & Sw & xviii \\
\hline \multirow[t]{3}{*}{$\mathrm{O}$} & Left tonsil & $\mathrm{Oa}$ & Sw & $\mathrm{xx}$ \\
\hline & Right tonsil & $\mathrm{Ob}$ & Sw & ND \\
\hline & Tongue & Oc & Sw & $\mathrm{xxi}$ \\
\hline \multirow[t]{3}{*}{$\mathbf{P}$} & Denture & $\mathrm{Pa} \ddagger$ & Sw & xxii \\
\hline & Palate & $\mathrm{Pb}$ & Sw & xxii \\
\hline & Tongue & Pc & Sw & xxii \\
\hline \multirow[t]{3}{*}{ Q } & Denture & Qał & Sw & xxii \\
\hline & Tongue & $\mathrm{Qb}$ & Sw & xxii \\
\hline & Palate & Qc & Sw & xxii \\
\hline \multirow[t]{2}{*}{$\mathbf{R}$} & Ridge & $\mathrm{Ra}$ & $\mathrm{Sw}$ & xxii \\
\hline & Denture & $\mathrm{Rb} \ddagger$ & Sw & xxii \\
\hline
\end{tabular}

Sw, smooth, white colony phenotype; rough, R/Edge, colony with rough surface texture (due to aerial mycelia) but with a regular edge; ND, not done.

* Isolate from the primary infection.

+ Isolate from a secondary infection.

† Isolate associated with denture stomatitis.

Generally, all of the isolates of a particular genotype (from each patient) produced germ tubes to the same extent. The ability to form germ tubes varied among the isolates associated with dentures; in half of the isolates, $60-95 \%$ of cells produced germ tubes, and in the remaining half, $<40 \%$ of cells produced germ tubes. Germ tube formation was also varied among reinfecting strains.

\section{Discussion}

In the present study, the genotypic relationships of 57 isolates of $C$. albicans from patients in the same geographical locale (Western Australia), were determined. The isolates were obtained from a group of patients who wore dentures and another group who did not wear dentures. The denture wearers were 
Table III. Percentage germ tube (GT) formation by the $C$. albicans isolates in vitro

\begin{tabular}{lccccccc}
\hline Isolate & $\begin{array}{l}\mathrm{GT} \\
(\%)\end{array}$ & Isolate & $\begin{array}{r}\mathrm{GT} \\
(\%)\end{array}$ & Isolate & $\begin{array}{r}\mathrm{GT} \\
(\%)\end{array}$ & Isolate & $\begin{array}{r}\mathrm{GT} \\
(\%)\end{array}$ \\
\hline $\mathrm{Aa}$ & 25 & $\mathrm{Fa}$ & 40 & $\mathrm{Ka}$ & 5 & $\mathrm{Nc}$ & 5 \\
$\mathrm{Ba}$ & 95 & $\mathrm{Fb}$ & 5 & $\mathrm{~Kb}$ & 10 & $\mathrm{Nd}$ & 10 \\
$\mathrm{Bb}$ & 95 & $\mathrm{Fc}$ & 5 & $\mathrm{Kc}$ & 10 & $\mathrm{Ne}$ & 60 \\
$\mathrm{Ca}$ & 85 & $\mathrm{Fd}$ & 95 & $\mathrm{Kd}$ & 15 & $\mathrm{Oa}$ & 50 \\
$\mathrm{Cb}$ & 95 & $\mathrm{Ga}$ & 20 & $\mathrm{Ke}$ & 70 & $\mathrm{Ob}$ & 10 \\
$\mathrm{Da}$ & 95 & $\mathrm{~Gb}$ & 50 & $\mathrm{La}$ & 60 & $\mathrm{Oc}$ & 10 \\
$\mathrm{Db}$ & 90 & $\mathrm{Gc}$ & 95 & $\mathrm{Lb}$ & 85 & $\mathrm{~Pa}$ & 10 \\
$\mathrm{Dc}$ & 90 & $\mathrm{Ha}$ & 60 & $\mathrm{Ma}$ & 65 & $\mathrm{~Pb}$ & 5 \\
$\mathrm{Dd}$ & 95 & $\mathrm{Hb}$ & 60 & $\mathrm{Mb}$ & 65 & $\mathrm{Pc}$ & 5 \\
$\mathrm{De}$ & 90 & $\mathrm{Hc}$ & 95 & $\mathrm{Mc}$ & 10 & $\mathrm{Qa}$ & 40 \\
$\mathrm{Df}$ & 5 & $\mathrm{Ia}$ & 95 & $\mathrm{Md}$ & 95 & $\mathrm{Qb}$ & 70 \\
$\mathrm{Dg}$ & 95 & $\mathrm{Ib}$ & 95 & $\mathrm{Me}$ & 60 & $\mathrm{Qc}$ & 20 \\
$\mathrm{Dh}$ & 80 & $\mathrm{Ja}$ & 10 & $\mathrm{Mf}$ & 75 & $\mathrm{Ra}$ & 40 \\
$\mathrm{Di}$ & 95 & $\mathrm{Jb}$ & 5 & $\mathrm{Na}$ & 50 & $\mathrm{Rb}$ & 25 \\
$\mathrm{Ea}$ & 5 & $\mathrm{Jc}$ & 15 & $\mathrm{Nb}$ & 10 & & \\
& & & & & & &
\end{tabular}

diagnosed as having candida-induced denture stomatitis. The DNA profiles of the isolates were obtained by hybridisation of the $C$. albicans-specific DNA probe, $27 \mathrm{~A}$, on two separate occasions - immediately after the isolates were obtained and 6 months later, after several passages on SAB plates and in YEPD broth. The 57 isolates could be divided reproducibly into 22 distinct groups based on a comparison of the their DNA profiles. Generally, the oral cavity of each of the 18 patients was colonised by a unique strain of C. albicans. This genetic diversity is similar to that observed in other studies of infecting $C$. albicans strains isolated from the oral cavities of non-immunocompromised individuals ${ }^{7}$ as well as HIV-infected patients. ${ }^{15}$ The majority of the $C$. albicans isolates from different sites within the oral cavity of an individual patient were found to belong to the same genetic group. The dominance of single $C$. albicans strains within the oral cavity of immunodeficient patients has been reported. Pittet et al. ${ }^{16}$ demonstrated the persistence of $C$. albicans strains with the same electrophoretic karyotype over a period of 6 months. Millon et $a{ }^{17}$ demonstrated the persistence of the same $C$. albicans strain in the oral cavity of HIVinfected patients for up to a year. These findings suggest that the oral cavity of each patient provides a unique micro-environment in which a particular $C$. albicans strain dominates.

In three of the five patients who had a secondary infection, a new $C$. albicans strain was isolated from the oral cavity during the second infection. However, in three patients the re-emergence of the original infecting strain occurred in the secondary infection. In one of the five patients, the secondary infection was associated with both the re-emergence of the original strain and the appearance of a new strain. The suppression of the original colonising isolate by the antifungal therapy presumably provided an opportunity for the new strain to become established in the oral cavity after cessation of the therapy. Other studies have also shown that re-infection may be due to either relapse or strain substitution and replacement. ${ }^{18}$ The re-emergence of the original $C$. albicans strain suggests that either the antifungal therapy was not completely effective or that this strain, presumably the patient's own commensal strain, was re-introduced into the oral cavity from another site within the patient. The persistence of $C$. albicans strains following antifungal therapy has been reported in HIV-infected patients with recurrent oral candidosis. ${ }^{17}$

The strains of $C$. albicans associated with dental plates did not fall into a single distinct genetic group (table II). In nine of 11 patients with dentures, the strain associated with dentures was the same as strains elsewhere within the oral cavity of the infected patient. Only in two patients ( $M$ and $N$ ) were the strains isolated from the dentures during the primary infection different from those isolated during the secondary infection. Therefore, it is likely that the denture stomatis was due to the overgrowth of commensal strains in the oral cavities of the patients. The genetic diversity of the $C$. albicans strains associated with the denture stomatitis appears to rule out the existence of specific hypervirulent strains associated with the infection. Similar conclusions have been made from the analysis of $C$. albicans strains associated with oral candidosis in immunocompromised patients. ${ }^{8,15}$

Germ tube formation has been suggested as an important virulence factor in $C$. albicans isolates associated with denture stomatitis. ${ }^{19} \mathrm{~A}$ germ tubenegative strain of $C$. albicans failed to induce palatal candidosis in the Wistar rat although the isolate was able to colonise oral mucosa. In the present study, all of the C. albicans isolates examined were able to form germ tubes in vitro. However, the percentage of blastospores that formed germ tubes ranged from $5 \%$ to $95 \%$, depending on the isolate. The percentage of germ tube formation generally correlated with the genotype of the isolate. However, there was no correlation between the extent of germ tube formation and the association of a particular strain with denture stomatitis. While the ability to form germ tubes may be an important virulence factor in denture stomatitis, the extent of germ tube formation did not correlate with infection. This suggests that other putative virulence factors of $C$. albicans, such as candida acid proteinase, may be more critical in denture stomatitis.

The predominant colony phenotype in all of the isolates was a smooth, white (Sw) phenotype, irrespective of the site of isolation. However, greater variation in colony phenotype was seen in the isolates from the secondary infection. The greater variation in colony phenotype of these strains compared to the original isolate may be due to the adaptation of the isolate to its new niche.

The variety of genotypes identified in this study suggests that no one particular virulent strain of $C$. albicans is associated with denture stomatitis. The overlap in genotypes of isolates associated with denture stomatitis with those from patients who were edentulous suggests that commensal strains were 
primarily responsible for the denture-associated infection. Secondary infection following anti-fungal therapy is due to the re-emergence of the original infecting strain or the emergence of a new strain, presumably from an exogenous source, or both.

\section{References}

1. Arendorf TM, Walker DM. The prevalence and intra-oral distribution of Candida albicans in man. Arch Oral Biol 1980; 25: 1-10.

2. Welch K, Finkbeiner W, Alpers CE et al. Autopsy findings in the acquired immuno-deficiency syndrome. JAMA 1984; 252: 1151-1159.

3. Odds FC. Candida and candidosis, 2nd edn. London, Bailliere Tindall 1988: 468 .

4. Kirkpatrick $\mathrm{CH}$. Chronic mucocutaneous candidiasis. Eur $J$ Clin Microbiol Infect Dis 1989; 8: 448-456.

5. Schmid J, Odds FC, Wiselka MJ, Nicholson KG, Soll DR, Genetic similarity and maintenance of Candida albicans strains from a group of AIDS patients, demonstrated by DNA fingerprinting. $J$ Clin Microbiol 1992; 30: 935-941.

6. Schmid J, Rotman M, Reed B, Pierson CL, Soll DR. Genetic similarity of Candida albicans strains from vaginitis patients and their partners. J Clin Microbiol 1993; 31: $39-46$.

7. Hellstein J, Vawter-Hugart H, Fotos P, Schmid J, Soll DR. Genetic similarity and phenotypic diversity of commensal and pathogenic strains of Candida albicans isolated from the oral cavity. J Clin Microbiol 1993; 31: 3190-3199.

8. Whelan WL, Kirsch DR, Kwon-Chung KJ, Wahl SM, Smith PD. Candida albicans in patients with the acquired immunodeficiency syndrome: absence of a novel or hypervirulent strain. J Infect Dis 1990; 162: 513-518.

9. Soll DR, Galask R, Schmid J, Hanna C, Mac K, Morrow B. Genetic dissimilarity of commensal strains of Candida spp. carried in different anatomical locations of the same healthy women. J Clin Microbiol 1991; 29: 1702-1710.

10. Scherer S, Stevens DA. A Candida albicans dispersed, repeated
We thank Professor S. Scherer, Department of Microbiology, University of Minnesota School of Medicine, Minneapolis, MN 55455, USA, for the gift of the $C$. albicans mid-repetitive DNA probe $27 \mathrm{~A}$. This work was supported by the National Health and Medical Research Council of Australia and the Child Health Research Foundation of Western Australia. gene family and its epidemiologic applications. Proc Natl Acad Sci USA 1988; 85: 1452-1456.

11. Mathaba LT, Franklyn KM, Warmington JR. A rapid technique for the isolation of DNA from clinical isolates of Candida albicans. J Microbiol Methods 1993; 17: 17-26.

12. Reed KC, Mann DA. Rapid transfer of DNA from agarose gels to nylon membranes. Nucleic Acids Res 1985; 13: 7207-7221.

13. Feinberg AP, Vogelstein B. A technique for radiolabeling DNA restriction endonuclease fragments to high specific activity. Anal Biochem 1983; 132: 6-13. Addendum: A technique for radiolabeling DNA restriction endonuclease fragments to high specific activity. Anal Biochem 1984; 137: 266-267.

14. Felsenstein J. PHYLIP (Phylogeny Inference Package) Version 3.2p. Cladistics 1989; 5: 164-166.

15. McCullough MJ, Ross BC, Dwyer BD, Reade PC. Genotype and phenotype of oral Candida albicans from patients infected with the human immunodeficiency virus. Microbiologica 1994; 140: 1195-1202.

16. Pittet D, Monod M, Filthuth I, Frenk E, Suter PM, Auckenthaler R. Contour-clamped homogeneous electric field gel electrophoresis as a powerful epidemiologic tool in yeast infections. Am J Med 1991; 91 (3B): 256S-263S.

17. Millon L, Manteaux A, Reboux G et al. Fluconazole-resistant recurrent oral candidiasis in human immunodeficiency virus-positive patients: persistence of Candida albicans strains with the same genotype. J Clin Microbiol 1994; 32 : 1115-1118.

18. Soll DR, Staebell M, Langtimm C, Pfaller M, Hicks J, Rao TVG. Multiple Candida strains in the course of a single systemic infection. J Clin Microbiol 1988; 26: 1448-1459.

19. Martin MV, Craig GT, Lamb DJ. An investigation of the role of true hypha production in the pathogenesis of experimental oral candidosis. Sabouraudia 1984; 22 : 471-476. 